\title{
Generation of

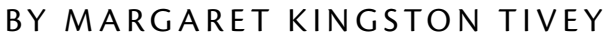 \\ Seafloor Hydrothermal Vent Fluids and Associated Mineral Deposits
}

In the nearly 30 years since the discovery of hydrothermal venting along open-ocean spreading centers, much has been learned about the generation of vent fluids and associated deposits. The hot, reducing, metal-rich, magnesium- and sulfatepoor hydrothermal fluids that exit "black smoker" and "white smoker" chimneys are formed through interactions of seawater with oceanic crust. These interactions (1) modify the composition of oceanic crust, (2) affect ocean chemistry, (3) form metal-rich deposits (possible analogs to ore deposits present on land), and (4) provide energy sources for biological communities in the deep sea.

The discovery of seafloor vents was a result of a number of factors. It came about in part through hypothesis-driven inquiry, which predicted that hydrothermal activity at midocean ridges is a logical outgrowth of plate-tectonic theory. Measurements of heat flow near ridge crests showed scattered values, with many significantly lower than values predicted for cooling of newly emplaced oceanic crust by conduction alone, consistent with transport of heat near ridge crests via convection of fluid (e.g., Talwani et al., 1971). Technological advances that allowed deep diving in occupied submersibles also played a role, allowing views of the seafloor at the scale needed to observe and sample active vents. But there were also aspects of exploration and serendipity involved. While those on the 1977 vent-discovery cruise had predicted the presence of warm fluids, they had not foreseen the unusual biological communities that were found to thrive in these environments (Corliss et al., 1979). And while some had anticipated the eventual discov- ery of high-temperature fluids and metal-rich deposits based on studies of fossil deposits uplifted and exposed on land (see review by Skinner, 1983), the expectation was that these might be the exception, not the rule.

Thirty years later, we now know the role these systems play in transferring mass and energy from the crust and mantle to the oceans. Hydrothermal circulation has proven to be an important sink for $\mathrm{Mg}$ and a source for other elements such as $\mathrm{Fe}, \mathrm{Mn}, \mathrm{Li}, \mathrm{Rb}$, and $\mathrm{Cs}$; thus it affects ocean chemistry (Von Damm et al., 1985). Analogs for ore deposits have been discovered, as have unusual biological communities (see Fisher et al., this issue). Compilations of global data demonstrate that, in general, the heat flux from venting along sections of midocean ridges is roughly proportional to spreading rate (though at ultraslow-spreading ridges, estimates of heat flux based on plume incidence fall off of this trend, and are significantly greater than predicted [Baker et al., 1995, 2004]). Investigations of individual vent fields along fast-, medium-, and slowspreading ridges, however, have produced the less-intuitive observation that the largest individual vent deposits tend to be found on slower-spreading ridges (Hannington et al., 1995). Through comparisons of systems in different tectonic settings, in substrates of different compositions, and at different depths in the ocean (Figure 1), coupled with data from laboratory and theoretical experiments, significant progress has been made in understanding the factors that control vent-fluid and deposit composition (e.g., see recent reviews by German and Von Damm [2004] and Hannington et al. [2005]). 


\title{
By comparing the fluids and deposits formed in distinct
}

\section{geologic and tectonic settings, it is possible to examine the role}

\section{that specific factors play in determining fluid composition ...}

\author{
and mineral deposit size, shape, and composition ...
}

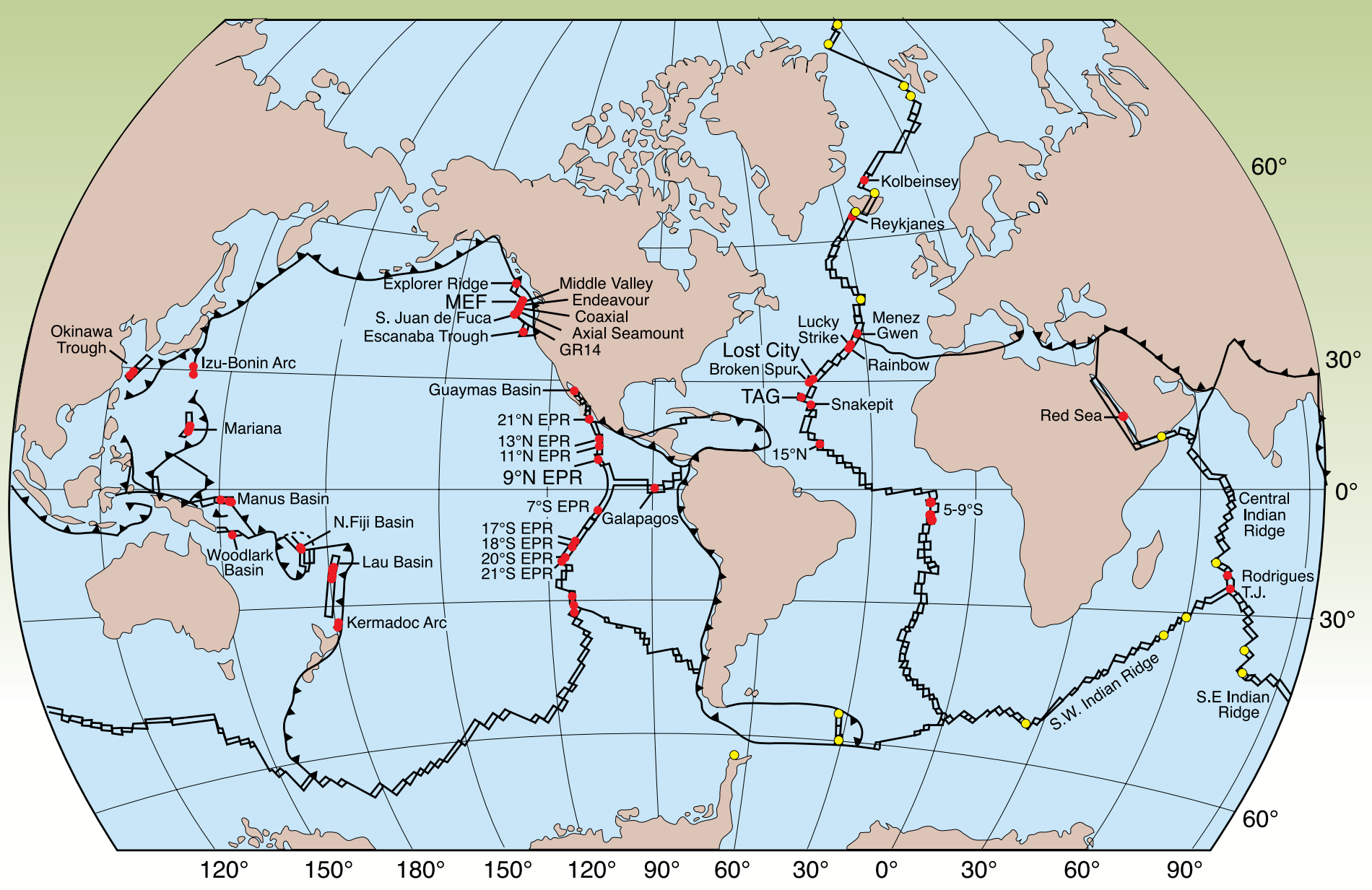

Figure 1. Known sites of hydrothermal venting along mid-ocean ridges, in back-arc basins, rifted arcs, and at submerged island-arc volcanoes (red), and areas of activity as indicated by mid-water chemical anomalies (yellow). EPR= East Pacific Rise. TAG $=$ Trans Atlantic Geotraverse, MEF = Main Endeavour Field, and GR-14 = Sea Cliff hydrothermal field on the northern Gorda Ridge. Figure after Baker et al., 1995; German and Von Damm, 2004; Hannington et al., 2005; Koschinsky et al., 2006 


\section{GENERATION OF SEAFLOOR}

\section{HYDROTHERMAL FLUIDS}

\section{THROUGH WATER-ROCK}

\section{INTERACTION}

Circulation of fluids within the oceanic crust at spreading centers occurs because of the presence of a heat source (magma or newly solidified hot rock), a permeable medium (faulted and fissured igneous crust), and a fluid that saturates the crust (seawater). The composition of hot fluids that exit at vent fields reflects a number of factors: the initial fluid composition (seawater); the composition of the rock that reacts with the fluid as it circulates and the structure of that rock (e.g., the distribution of fractures and fissures, the depth to the brittle/ductile transition); and the depth, size, and shape of the heat source (Figure 2a).
These factors affect the depth and scale of fluid circulation, the temperature and pressure at which water-rock reactions take place, and whether the fluid undergoes phase separation. Most mid-ocean ridge vent fields are hosted within basalt, and chemical reactions occur as fluids circulate, first at low temperatures in the down-flowing limb or "recharge" zone, then at much higher temperatures in the
Figure 2. (a) Schematic drawing of a hydrothermal system within oceanic crust showing the different components and processes that can affect the composition of the fluid that vents at the seafloor (e.g., initial fluid composition, substrate composition, permeability structure of the substrate, and geometry and nature of heat source, all of which contribute to the temperatures and pressures at which reactions occur). (b) Elaboration of the processes that contribute to formation of midocean ridge vent fluids. As seawater penetrates down into the crust, basaltic glass, olivine, and plagioclase are altered to ferric micas, smectite, and Fe-oxyhydroxides at low temperatures $\left(40^{\circ} \mathrm{C}-60^{\circ} \mathrm{C}\right)$. As the modified fluid penetrates deeper into the crust and is heated to higher temperatures, precipitation of smectite and chlorite results in removal of $\mathrm{Mg}$ from the fluid in exchange for $\mathrm{Ca}^{2+}, \mathrm{H}^{+}$, and $\mathrm{Na}^{+} . \mathrm{Ca}^{2+}$ and $\mathrm{SO}_{4}{ }_{4}$ are lost from the fluid as anhydrite $\left(\mathrm{CaSO}_{4}\right)$ precipitates at temperatures greater than $150^{\circ} \mathrm{C}$. Deeper in the system, anorthite is altered to albite, a process called albitization, with $\mathrm{Na}$ and $\mathrm{Si}$ being added to the crust in exchange for $\mathrm{Ca}$, which is released from the rock into the fluid. The sum of these reactions results in a fluid that is slightly acid, anoxic, alkali-rich, and $\mathrm{Mg}$-poor relative to seawater. This fluid then leaches $S$ and metals from the rock. Volatiles from magma $\left(\mathrm{He}, \mathrm{CO}_{2}, \mathrm{CH}_{4}, \mathrm{H}_{2}\right)$ may be added, further modifying the fluid composition. Further fluid modification can occur from separation of the fluid into a low-salinity, vapor-rich phase and a brine phase if the temperatures and pressures exceed those of the boiling curve. Lastly, as the hot, buoyant fluids rise rapidly to the seafloor, there may be some equilibration, with minor amounts of precipitation and/or dissolution of sulfide phases as the fluid rises. Quartz becomes saturated, but does not precipitate due to kinetic barriers. Close to the seafloor, the fluid may exit directly into the ocean, or be modified in the subsurface if seawater is entrained in the vicinity of the vents.
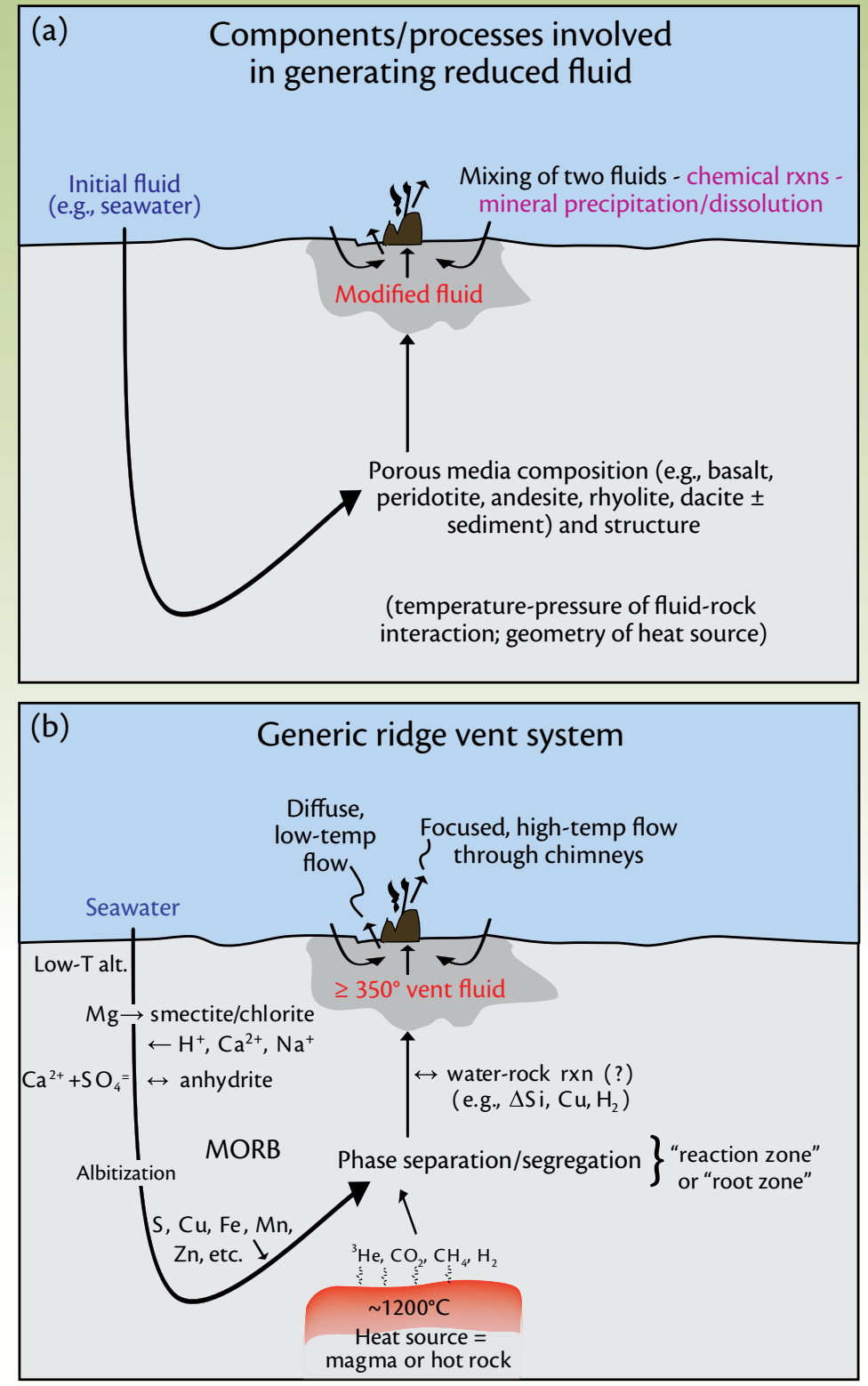
deepest portions of the circulation system (the "root" or "reaction" zone), and lastly as the hot, buoyant fluid rises rapidly through the "up-flow" zone to exit at the seafloor (Alt, 1995) (Figure 2b).

Our understanding of processes occurring in the down-flowing limb relies largely on data and observations of alteration mineral assemblages within oceanic crust recovered by submersible from fractures and scarps that expose deeper parts of the crust, from drill cores, and from ophiolites (slices of oceanic crust that have been thrust onto land by platetectonic processes). At temperatures up to about $40^{\circ} \mathrm{C}$ to $60^{\circ} \mathrm{C}$, reactions of seawater with basalt result in the alteration of basaltic glass, olivine, and plagioclase by oxidation to ferric micas and smectite, Mg-rich smectite, and Fe oxyhydroxides
(Figure 3a), with alkali metals $(\mathrm{K}, \mathrm{Rb}$, Cs), $\mathrm{B}$, and $\mathrm{H}_{2} \mathrm{O}$ removed from seawater to the altered minerals and $\mathrm{Si}, \mathrm{S}$, and, in some cases, $\mathrm{Mg}$, lost from the minerals

MARGARET KINGSTON TIVEY (mktivey@ whoi.edu) is Associate Scientist, Department of Marine Chemistry and Geochemistry, Woods Hole Oceanographic Institution, Woods Hole, MA, USA.
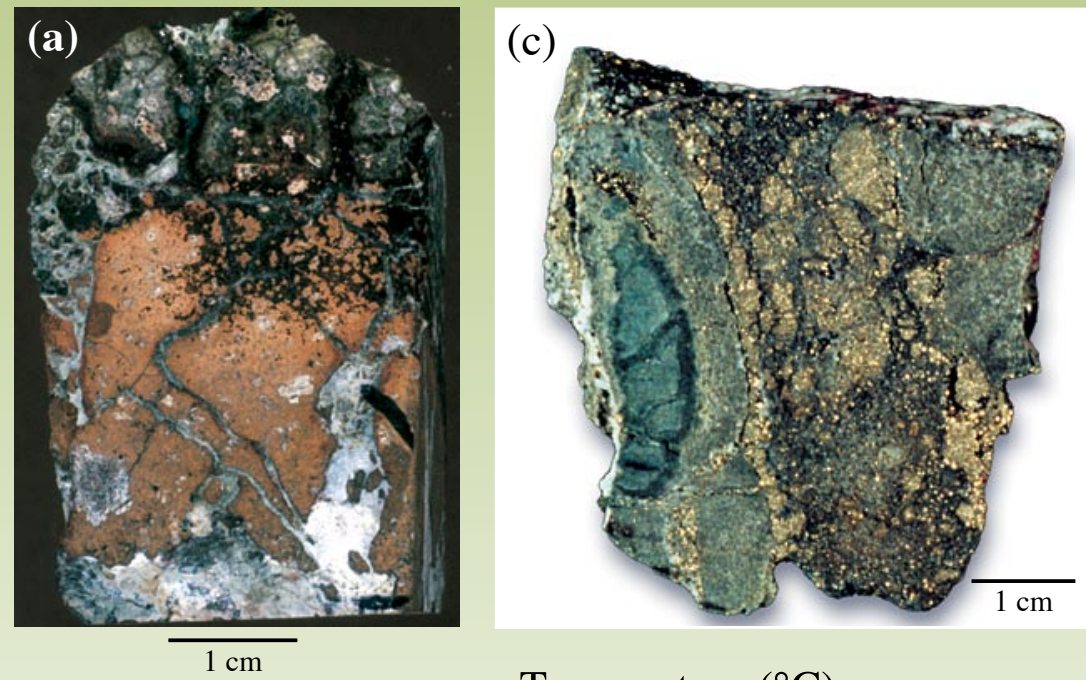

(b)

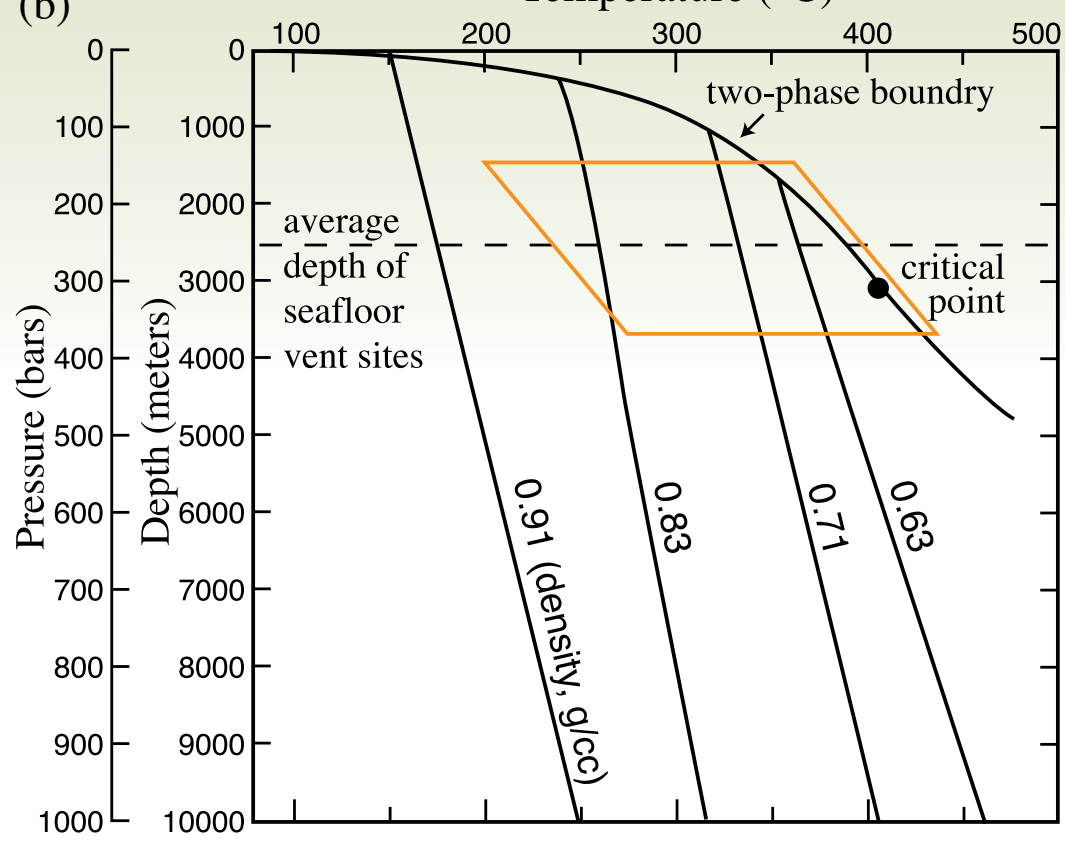

Figure 3. (a) Altered basalt recovered on Ocean Drilling Program (ODP) Leg 51 from Hole 417a, composed of ferric smectites and Fe-oxyhydroxides (red-brown) that replace plagioclase, olivine, and basaltic glass; and veins of carbonate (white). (b) The two-phase boundary, critical point, and density surfaces for seawater as a function of temperature and pressure, or depth beneath the seafloor, assuming hydrostatic pressure (after Bischoff and Rosenbauer, 1985). The red parallelogram indicates temperatures and pressures of venting observed at the seafloor in different locations along the world's spreading centers. (c) A piece of stockwork, or chloritized basalt breccia, recovered from $116 \mathrm{~m}$ beneath the TAG active hydrothermal mound on ODP Leg 158. The sample is composed of highly altered chloritized basalt (gray-green), iron sulfide veins (gold), and quartz cement. Photos courtesy of S. Humphris (Woods Hole Oceanographic Institution and Ocean Drilling Program) 
to the fluid (see review by Alt, 1995).

As seawater penetrates deeper and is heated to temperatures above $\sim 150^{\circ} \mathrm{C}$, $\mathrm{Mg}$ is removed from the fluid through precipitation of clays, such as Mg-rich smectite and chlorite at temperatures less than and greater than $200^{\circ} \mathrm{C}$, respectively (Alt, 1995). Mg removal can be represented by Reaction 1, showing chlorite formation.

The reactions are important, both in affecting the seawater Mg budget and also in making the recharge seawater more acidic. However, $\mathrm{H}^{+}$formed by $\mathrm{Mg}$ fixation is also consumed by silicate hydrolysis reactions. For example, results of experimental reaction of seawater with basalt demonstrate that uptake of Mg by the rock is roughly balanced by release of Ca (Mottl, 1983).

Significant Ca is also lost from seawater as a result of anhydrite formation. Anhydrite $\left(\mathrm{CaSO}_{4}\right)$ has retrograde solubility and precipitates from seawater at temperatures in excess of $\sim 150^{\circ} \mathrm{C}$ (Bischoff and Seyfried, 1978). Its precipitation removes all of the Ca from seawater and about one-third of seawater sulfate. Additional anhydrite precipitation can occur following release of $\mathrm{Ca}$ into the fluid from basalt. That significant $\mathrm{Ca}$ is released from the rock is demonstrated by the presence of $\mathrm{Ca}$ in hydrothermal fluids venting at the seafloor. Other reactions that affect fluid composition in the down-flowing limb include reaction of water with ferrous Fe-bearing minerals (e.g., olivine, pyroxene, pyrrhotite), which results in reducing conditions (high $\mathrm{H}_{2}$ concentrations). Reduction of seawater sulfate occurs, which results in the observed slightly elevated $\delta^{34} S$ values of hydrothermal sulfide in altered sheeted dikes and in fluids venting at the seafloor $(\geq 1 \%$ vs. 0\%o for basaltic sulfide) (Alt, 1995). Ion exchange reactions also occur, including albitization, which affects the concentrations of $\mathrm{Ca}$ and $\mathrm{Na}$ in the resulting vent fluid through alteration of anorthite to albite (Alt, 1995) (Reaction 2).

The sum of reactions occurring in the recharge zone (Figure $2 b$ ) results in a fluid that is slightly acidic, anoxic, and alkali-rich and $\mathrm{Mg}$-poor relative to the starting seawater. This fluid then leaches $\mathrm{S}$ and metals (e.g., $\mathrm{Cu}, \mathrm{Fe}, \mathrm{Mn}, \mathrm{Zn}$ ) from the rock into solution in the deep reaction (e.g., Alt 1995) or root zone (e.g., Butterfield et al., 2003) $\left(\sim 425^{\circ} \mathrm{C}\right.$ at $\sim 400$ to 500 bars). If the fluid temperature and pressure exceed those of the boiling curve for seawater (Figure 3b), the fluid will separate into a low-salinity, vapor-rich phase and a brine phase. During this partitioning, volatiles (e.g., $\mathrm{H}_{2} \mathrm{~S}$ ) partition preferentially into the vapor-rich phase (Von Damm, 1995). Most vent fluids exhibit a chloride composition either significantly greater or less than that of seawater, which is consistent with phase separation being the rule rather than the exception (e.g., Von Damm, 1995) (Table 1). The large differences in chloride also affect metal contents as most metal ions are carried in the fluid at high temperatures as chloride complexes (e.g., $\mathrm{FeCl}_{2}(\mathrm{aq})$ ) (Helgeson et al., 1981). Evidence of phase separation is also found in the rock record, where small amounts of fluids trapped in minerals as fluid inclusions exhibit salinities both greater and less than seawater (e.g., Delaney et al., 1987; Vanko 1988; Kelley et al., 1993).

A final process that can affect vent fluid compositions is the addition of magmatic volatiles to the circulating fluid, such as ${ }^{3} \mathrm{He}, \mathrm{CO}_{2}, \mathrm{CH}_{4}$, and $\mathrm{H}_{2}$ (Alt, 1995). In some back-arc and arc

\section{REACTION 1 \\ $4(\mathrm{NaSi})_{0.5}(\mathrm{CaAl})_{0.5} \mathrm{AlSi}_{2} \mathrm{O}_{8}+15 \mathrm{Mg}^{2+}+24 \mathrm{H}_{2} \mathrm{O} \Rightarrow 3 \mathrm{Mg}_{5} \mathrm{Al}_{2} \mathrm{Si}_{3} \mathrm{O}_{10}(\mathrm{OH})_{8}+\mathrm{SiO}_{2}+2 \mathrm{Na}^{+}+2 \mathrm{Ca}^{2+}+24 \mathrm{H}^{+}$ \\ Albite-Anorthite in Basalt \\ Chlorite}

\section{REACTION 2}

$$
\mathrm{CaAl}_{2} \mathrm{Si}_{2} \mathrm{O}_{8}+2 \mathrm{Na}^{+}+4 \mathrm{SiO}_{2}(\mathrm{aq}) \Rightarrow 2 \mathrm{NaAlSi}_{3} \mathrm{O}_{8}+\mathrm{Ca}^{2+}
$$

Anorthite Albite 
systems where magma is more siliceous and richer in $\mathrm{H}_{2} \mathrm{O}$, very-low-pH fluids are observed, consistent with addition of magmatic $\mathrm{SO}_{2}$ that disproportionates to form sulfuric acid (e.g., Gamo et al., 1997). Some of these back-arc- and arcrelated magmatic fluids may also con- tribute metals to the hydrothermal system (e.g., $\mathrm{Cu}, \mathrm{Zn}, \mathrm{Fe}, \mathrm{As}, \mathrm{Au}$ ) (Ishibashi and Urabe, 1995; Yang and Scott, 1996; Hannington et al., 2005).

The evolved fluid in the root or reaction zone is very buoyant relative to cold seawater (Figure $3 \mathrm{~b}$ ) and thus rises at a rapid rate to the seafloor. Observations of the rock record, which integrate the effects of water-rock interaction over long time periods, combined with results of thermodynamic calculations that consider the measured compositions of fluids sampled at vents, indicate that the

Table 1. Compositions of fluids venting from different settings.

\begin{tabular}{|l|c|c|c|c|c|c|}
\hline & $\begin{array}{c}\text { Mid-Ocean } \\
\text { Ridge }\end{array}$ & Back-Arc & Rainbow & Lost City & $\begin{array}{c}\text { Sediment- } \\
\text { Hosted }\end{array}$ & Seawater \\
\hline $\mathrm{T}\left({ }^{\circ} \mathrm{C}\right)$ & $\leq 405$ & $278-334$ & 365 & $\leq 91$ & $100-315$ & 2 \\
\hline $\mathrm{pH}\left(25^{\circ} \mathrm{C}\right)$ & $2.8-4.5$ & $<1-5.0$ & 2.8 & $10-11$ & $5.1-5.9$ & 8 \\
\hline $\mathrm{Cl}, \mathrm{mmol} / \mathrm{kg}$ & $30.5-1245$ & $255-790$ & 750 & 548 & $412-668$ & 545 \\
\hline $\mathrm{Na}, \mathrm{mmol} / \mathrm{kg}$ & $10.6-983$ & $210-590$ & 553 & $479-485$ & $315-560$ & 464 \\
\hline $\mathrm{Ca}, \mathrm{mmol} / \mathrm{kg}$ & $4.02-109$ & $6.5-89$ & 67 & $<30$ & $160-257$ & 10.2 \\
\hline $\mathrm{K}, \mathrm{mmol} / \mathrm{kg}$ & $-1.17-58.7$ & $10.5-79$ & 20 & - & $13.5-49.2$ & 10.1 \\
\hline $\mathrm{Ba}, \mu \mathrm{mol} / \mathrm{kg}$ & $1.64-18.6$ & $5.9-100$ & $>67$ & - & $>12$ & 0.14 \\
\hline $\mathrm{H}{ }_{2} \mathrm{~S}, \mathrm{mmol} / \mathrm{kg}$ & $0-19.5$ & $1.3-13.1$ & 1 & $<0.064$ & $1.10-5.98$ & - \\
\hline $\mathrm{H}_{2}, \mathrm{mmol} / \mathrm{kg}$ & $0.0005-38$ & $0.035-0.5$ & 13 & $<1-15$ & - & - \\
\hline $\mathrm{CO},{ }^{\prime} \mathrm{mmol} / \mathrm{kg}$ & $3.56-39.9$ & $14.4-200$ & $n a$ & $b d l$ & - & 2.36 \\
\hline $\mathrm{CH}{ }_{4}, \mathrm{mmol} / \mathrm{kg}$ & $0.007-2.58$ & $.005-.06$ & $0.13-2.2$ & $1-2$ & - & - \\
\hline $\mathrm{NH}{ }^{\prime}, \mathrm{mmol} / \mathrm{kg}$ & $<0.65$ & - & - & - & $5.6-15.6$ & - \\
\hline $\mathrm{Fe}, \mu \mathrm{mol} / \mathrm{kg}$ & $7-18700$ & $13-2500$ & 24000 & - & $0-180$ & - \\
\hline $\mathrm{Mn}, \mu \mathrm{mol} / \mathrm{kg}$ & $59-3300$ & $12-7100$ & 2250 & - & $10-236$ & - \\
\hline $\mathrm{Cu}, \mu \mathrm{mol} / \mathrm{kg}$ & $0-150$ & $.003-34$ & 140 & - & $<0.02-1.1$ & - \\
\hline $\mathrm{Zn}, \mu \mathrm{mol} / \mathrm{kg}$ & $0-780$ & $7.6-3000$ & 160 & - & $0.1-40.0$ & - \\
\hline $\mathrm{Pb}, \mu \mathrm{mol} / \mathrm{kg}$ & $0.183-0.1630$ & $0.036-3.900$ & 0.148 & - & $<0.02-0.652$ & - \\
\hline $\mathrm{Co}, \mu \mathrm{mol} / \mathrm{kg}$ & $0.02-1.43$ & - & 13 & - & $<0.005$ & - \\
\hline $\mathrm{Cd}, \mu \mathrm{mol} / \mathrm{kg}$ & $0-0.910$ & - & 0.130 & - & $<0.01-0.046$ & - \\
\hline $\mathrm{Ni}, \mu \mathrm{mol} / \mathrm{kg}$ & - & - & 3 & - & - & - \\
\hline $\mathrm{SO}{ }_{4}, \mathrm{mmol} / \mathrm{kg}$ & 0 & 0 & 0 & $1-4$ & 0 & 28 \\
\hline $\mathrm{Mg}, \mathrm{mmol} / \mathrm{kg}$ & 0 & 0 & 0 & $<1$ & 0 & 53 \\
\hline
\end{tabular}

Data from Von Damm et al., 1985; Welhan and Craig, 1983; German and Von Damm, 2003; Trefry et al., 1994; Ishibashi and Urabe, 1995; Jeffrey S. Seewald, Woods Hole Oceanographic Institution, pers. comm., 2006; Douville et al., 2002; Kelley et al., 2001, 2005; Proskurowski et al., 2006. 
fluid does not attain equilibrium with the surrounding rock during ascent, though there may be some equilibration (e.g., of Si, $\mathrm{H}_{2}(\mathrm{aq}), \mathrm{Cu}$ ) (Von Damm, 1995; Ding and Seyfried, 1994). Quartz becomes saturated as the fluid rises (due to decreasing pressure), but does not precipitate due to kinetic barriers at the low $\mathrm{pH}$ of the fluids (and is not observed within actively forming chimneys), and there may be minor amounts of precipitation and/or dissolution of sulfide phases as the fluid rises. Over long time periods, results of minor amounts of reaction may be left in the rock record, such as epidote + quartz \pm chlorite assemblages observed in ophiolites (Alt, 1995), or the well-developed stockwork beneath vent fields, for example, at the Trans-Atlantic Geotraverse (TAG) active hydrothermal mound (Figure 3c), though in the latter case significant nearsurface entrainment of seawater has likely enhanced the amount of reaction.

While detailed experimental, theoretical, and field studies have been carried out that consider basalt-hosted hydrothermal activity, far fewer studies have been done considering alternative substrates, for example, andesite, rhyolite, dacite (present in back-arc basins, rifted arcs, and submerged island-arc volcanoes), peridotite (present along some portions of slow-spreading ridges), or sediment. Laboratory experiments of andesite-seawater interaction at a low water-rock ratio $(<5)$ suggest that alteration assemblages within the oceanic crust should be similar to those occurring when basalt and seawater interact, though resultant fluids were enriched in $\mathrm{Ca}, \mathrm{Mn}, \mathrm{Si}$, and Fe relative to fluids from basalt-seawater experiments
(Hajash and Chandler, 1981). Fluids sampled at vent fields hosted in andesite show elevated trace metals (e.g., Zn, Cd, $\mathrm{Pb}, \mathrm{As}$ ) (Fouquet et al., 1993a) (Table 1), but interpretation of these observations is complicated by observations of low$\mathrm{pH}$ fluids, where the low $\mathrm{pH}$ may reflect input of magmatic volatiles (e.g., magmatic $\mathrm{SO}_{2}$ ) (Gamo et al., 1997; Douville et al., 1999).

Theoretical and laboratory experiments of peridotite-seawater reaction at low water-rock ratios indicate that serpentine and talc may replace smectite as an alteration phase left in the oceanic crust and that high-temperature fluids should exhibit lower $\mathrm{Ca}, \mathrm{Si}, \mathrm{Mn}$, and Fe; slightly higher $\mathrm{pH}$; and much higher $\mathrm{CH}_{4}$ and $\mathrm{H}_{2}$ relative to fluids from basalt-seawater reaction at similar temperatures (Hajash and Chandler, 1981; Wetzel and Shock, 2000), though concentrations vary with differing proportions of olivine and pyroxene (Allen and Seyfried, 2003). Fluids from the peridotite-hosted Rainbow hydrothermal field (Mid-Atlantic Ridge), however, exhibit low $\mathrm{pH}$ and very high Fe relative to most mid-ocean ridge vent fluids (Douville et al., 2002) (Table 1). Laboratory and theoretical experiments that consider the slow rate of hydrolysis of olivine provide an explanation, indicating that dissolution of pyroxene can lead to a silica-rich fluid, tremolite formation, acid generation, and high Fe in the fluid relative to reaction of seawater with basalt (Allen and Seyfried, 2003).

Vent-fluid compositions can also be affected greatly by reaction with sediments. Factors affecting fluids in sediment-hosted systems include the composition of the sediment (e.g., abundances and types of organic matter, calcium carbonate, and clay), the structure of the sediment-rich oceanic crust (i.e., the presence of faults or sills that can affect fluid flow paths and temperatures of reaction), and amounts of unreacted sediment. Sediment composition largely reflects the source of the sediment, for example, whether it is dominantly from turbidites as at Middle Valley (Juan de Fuca Ridge, Northeast Pacific) or marine-derived as in the Guaymas Basin (East Pacific Rise, Gulf of California). In either case, the presence of carbonate and organic matter buffers the $\mathrm{pH}$ of the vent fluid (German and Von Damm, 2004). While fluids from vents in the Guaymas Basin, Middle Valley, and Escanaba Trough (Gorda Ridge), show a wide range in composition, all are similar in exhibiting a higher $\mathrm{pH}$ (5.1 to 5.9 at $25^{\circ} \mathrm{C}$ ) and lower metal contents than fluids formed in unsedimented settings (German and Von Damm, 2004) (Table 1).

Another controlling factor for ventfluid composition is the source of heat that drives hydrothermal convection and affects the temperatures and pressures at which reactions occur between fluid and substrate. The Lost City hydrothermal system, located $15 \mathrm{~km}$ from the axis of the Mid-Atlantic Ridge on the Atlantis Massif $\left(\sim 30^{\circ} \mathrm{N}\right)$, composed of mantle rocks (peridotite and serpentinite) and gabbro, is an excellent example (Kelley et al., 2001). It has been proposed that generation of Lost City fluids, and their associated mineral deposits and microbiologic communities, does not require heat from magma or cooling of recently solidified rock. Instead, the isotopic compositions of fluids venting at this 
field are consistent with formation from exothermic (heat-producing) serpentinization reactions (a result of seawatermantle peridotite interaction) at temperatures of $110^{\circ} \mathrm{C}$ to $150^{\circ} \mathrm{C}$, producing $\mathrm{Mg}$-poor, $\mathrm{CH}_{4}-$ and $\mathrm{H}_{2}$ - rich, very high $\mathrm{pH}(10-11)$ fluids that vent at the seafloor at temperatures up to $91^{\circ} \mathrm{C}$ (Kelley et al., 2001, 2005; Proskurowski et al., 2006). However, theoretical calculations to reproduce the chemical composition of the fluids, specifically the near-seawater values of $\mathrm{Cl}$ and $\mathrm{K} / \mathrm{Cl}$ and $\mathrm{Na} / \mathrm{Cl}$ ratios, coupled with heat balance models, suggest that exothermic reactions likely are not a significant source of heat to the system; it is more likely that the source of heat for the Lost City hydrothermal system is deep penetration of fluids and access to heat from hot rock or magma (Allen and Seyfried, 2004).

Further examination and further discovery of non-basalt-hosted hydrothermal systems is needed to resolve the roles that different processes, such as waterrock reaction at different temperatures and with different substrates, magmatic volatile input, and subsurface precipitation, play in determining the compositions of fluids that exit the seafloor.

\section{FORMATION OF SEAFLOOR} MINERAL DEPOSITS

Just as there are several key factors that control the composition of vent fluids, there are key factors that affect the formation and composition of the deposits that form within the crust and at the seafloor from interaction of these fluids with seawater. They include the composition and temperature of the fluid that rises from depth toward the seafloor (including its density) and the perme- ability structure of the oceanic crust and/ or deposits at the seawater/oceanic crust boundary and in the upper few hundred meters. These factors are important because they determine, in large part, the styles of mixing between the vent fluid and seawater. Some of these differences can be illustrated by comparing three distinctly different types of deposits located along mid-ocean ridges and hosted in basalt: those found on the fast-spreading East Pacific Rise, the intermediate-spreading Endeavour Segment of the Juan de Fuca Ridge, and the TAG active hydrothermal mound on the slow-spreading Mid-Atlantic Ridge (Figure 4). The effect that more drastic differences in vent-fluid compositions can have on the formation and composition of the deposits can be illustrated by comparing the structure and composition of basalt-hosted mid-ocean ridge deposits to deposits hosted in other substrates and geologic settings: those found in back-arc, rifted-arc, and submerged island-arc settings, and those found offaxis and hosted in peridotite.

\section{East-Pacific-Rise-Type \\ Vent Deposits}

Along the East Pacific Rise, active vent fields consist of combinations of small ( $<$ 10-m-diameter), low-lying mounds with individual 1-2-m-diameter structures that stand $<15 \mathrm{~m}$ high, formed by the coalescence of smaller chimneys (Haymon and Kastner, 1981; Goldfarb et al., 1983) (Figure 4a). The individual chimneys either vent hot fluid $\left(\sim 330^{\circ} \mathrm{C}\right.$ to $\left.405^{\circ} \mathrm{C}\right)$ directly into cold seawater, forming plumes of black precipitates (black "smoke") above the vent opening, or cooler fluids through the tops and sides of shimmering spires. Fluids venting from the hotter "black smoker" chimneys have not mixed with any entrained seawater during their ascent, as demonstrated by an absence of $\mathrm{Mg}$ in the sampled fluids (Von Damm et al., 1985). Study of the first black smokers sampled at $21^{\circ} \mathrm{N}$ on the East Pacific Rise led to a model of chimney formation that is still accepted today (Haymon, 1983; Goldfarb et al., 1983): When the hot, slightly acidic, metal-, sulfide-, and Ca-rich vent fluid exits at meters-persecond velocities into cold $\left(2^{\circ} \mathrm{C}\right)$, slightly alkaline, metal-poor, sulfate- and Carich seawater, anhydrite $\left(\mathrm{CaSO}_{4}\right)$ and fine-grained $\mathrm{Fe}, \mathrm{Zn}$, and $\mathrm{Cu}-\mathrm{Fe}$ sulfides precipitate. A ring of anhydrite deposited around the vent opening provides a barrier to direct mixing of vent fluid with seawater and a substrate on which other minerals can precipitate. Chalcopyrite $\left(\mathrm{CuFeS}_{2}\right)$ is deposited against the inner wall, and hydrothermal fluid and seawater "mix" via diffusion and advection through the newly emplaced wall. These processes result in sulfide and sulfate minerals becoming saturated and precipitating within pore spaces of the wall, which gradually becomes less permeable (Figure 5a). As long as the chimney conduit remains open, the majority of vent fluid exits at the top into seawater and rises in a large plume where abundant metals precipitate.

The style of mixing between vent fluid and seawater is vastly different in chimneys that vent lower-temperature, white to clear fluids $\left(<300^{\circ} \mathrm{C}\right.$ to $\left.330^{\circ} \mathrm{C}\right)$; much more of the metals in the fluid remain within the deposit as the fluid percolates less vigorously through the porous spires (Figure 5b) (Haymon and Kastner, 
(b) MEF Vent Structure

(a) EPR Vent Site
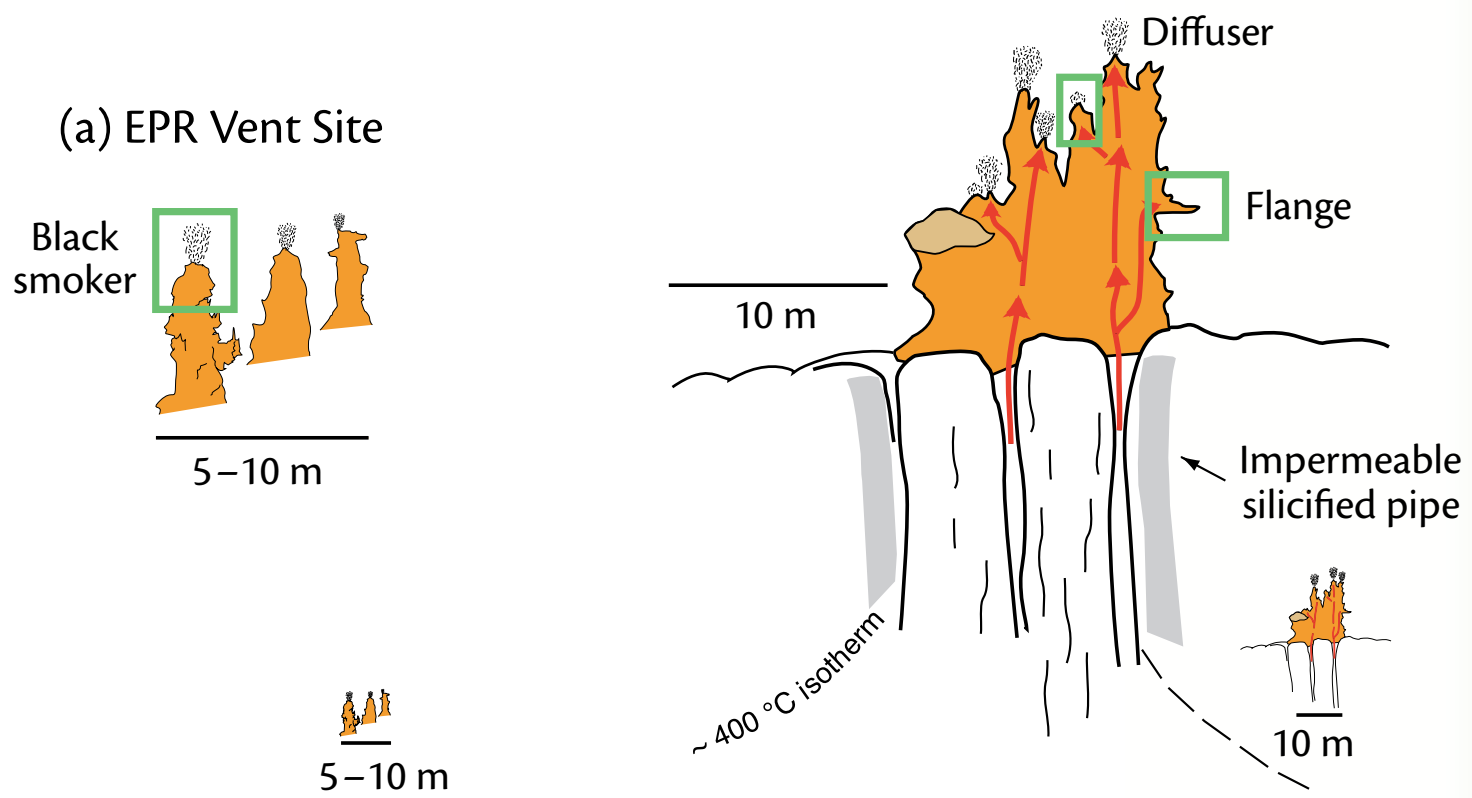

(C) TAG Active Hydrothermal Mound

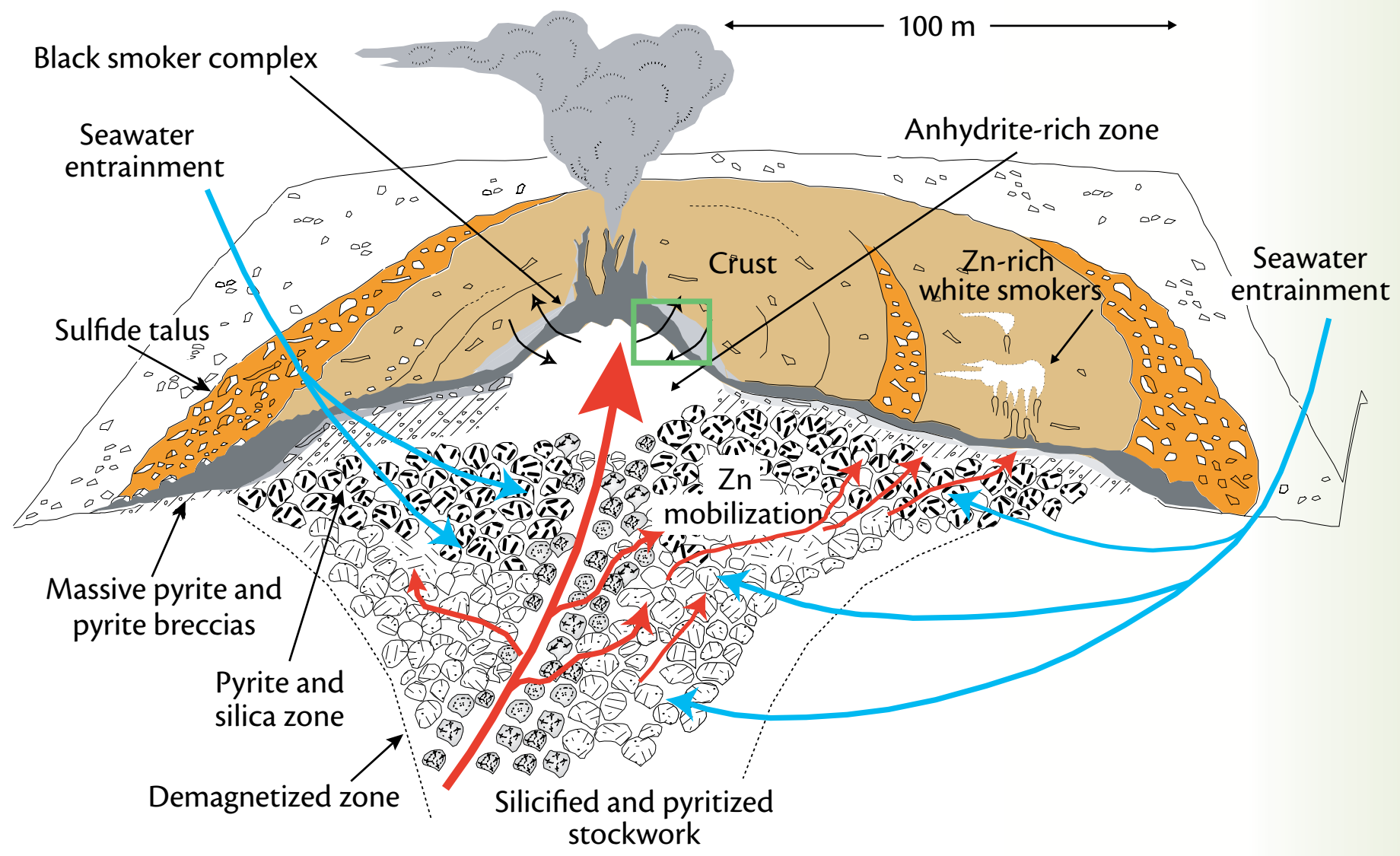


Figure 4. Schematic drawings showing the different size and morphology, and different processes affecting, vent structures from different tectonic and geologic settings. (a) An East Pacific Rise (EPR) vent site showing tall spires topped by black smoker chimneys. Total accumulation of mass at each vent site is low likely due to hot fluids passing through the structure into the plume above, coupled with eruption frequency that can bury deposits (based on photographs and data from Ferrini et al., in press). (b) A steepsided structure from the Main Endeavour Field (MEF) of the Juan de Fuca Ridge (after Hannington et al., 1995, and Sarrazin et al., 1997) that forms from deposition of minerals from a fluid that has a higher $\mathrm{pH}$ at temperatures less than $300^{\circ} \mathrm{C}$ due to the presence of ammonia in the fluid (Tivey et al., 1999). The entire MEF includes 15 structures and covers an area of $\sim 400 \times 200$ m (Delaney et al., 1992). It has also been proposed that the steep-sided Endeavour structures are underlain by pipelike stockworks, with intense silicification of the alteration pipes sealing the stockwork, preventing entrainment of seawater (Hannington et al., 1995). The presence of higher-pH fluids provides an explanation for the silicification (Tivey et al., 1999). (c) The Trans Atlantic Geotraverse (TAG) active hydrothermal mound is forming from vigorous venting through the black smoker, combined with significant entrainment of seawater into and beneath the mound. This process triggers: deposition of pyrite, chalcopyrite and anhydrite; generation of a more acidic fluid; and remobilization of $\mathrm{Zn}$ and other trace metals, which are then deposited at the outer edges and on the upper surface of the mound (after Humphris and Tivey, 2000). The very large size compared to structures from the EPR and MEF result from a combination of efficient mineral deposition because of seawater entrainment, and recurrence of hydrothermal activity at this same location over a period of 20,000 to 50,000 years. Examples of portions of structures outlined by green boxes are shown in Figure 5 .
1981; Koski et al., 1994). In contrast to black smoker chimneys, these spires often lack anhydrite, consistent with a lack of entrained seawater sulfate. Flow is through narrow, anastomosing conduits that seal with time, resulting in flow being diverted horizontally (Fouquet et al., 1993b; Koski et al., 1994; Tivey et al., 1995). Differences between these zincrich chimneys and the copper-rich black smoker chimneys provide information about the very different environmental (thermal, chemical) conditions that likely exist in their interiors and at their exteriors where micro-, macro-, and mega-fauna may reside.

At East Pacific Rise fields, lowertemperature, diffuse flow is also observed exiting from cracks and crevices in the basaltic seafloor (Haymon and Kastner, 1981). A recent comparison of high- and low-temperature fluids at the East Pacific Rise at $9^{\circ} \mathrm{N}$ showed that concentrations of many elements are consistent with cooler fluid forming from mixing of high-temperature fluid with seawater; however, the concentrations of some chemical species were not conservative with mixing, providing evidence for possible biological consumption of $\mathrm{H}_{2} \mathrm{~S}$ and $\mathrm{H}_{2}$ (and $\mathrm{CO}_{2}$ ) and production of $\mathrm{CH}_{4}$ (Von Damm and Lilley, 2004). Similar conclusions were reached in a study of low-temperature fluids exiting basalt at Axial Volcano on the Juan de Fuca Ridge (Butterfield et al., 2004).

Overall, the deposits at most East Pacific Rise vent fields are small because much of the fluid and precipitate is carried upward into plumes above the vent fields, and spreading rates are high and eruptions frequent so that deposits do not have time to attain a large size. The different styles of mixing between vent fluid and seawater that occur within black-smoker chimneys vs. more porous spires vs. within the subsurface provide a range of different thermal and chemical environments and potential habitats for the unusual fauna found at vents (see Fisher et al., this issue).

\section{Large, Steep-Sided "Endeavour" Type Structures-Flanges and Fluids with "Higher" pH}

At the Main Endeavour Field (MEF) on the Juan de Fuca Ridge, vent structures and styles of venting differ greatly from those on the East Pacific Rise, reflecting differences in the composition of the vent fluids rising from depth and in styles of mixing, and greater longevity of venting. Steep-sided structures rise nearly vertically from the seafloor to heights greater than 10 or 20 meters (Delaney et al., 1992) (Figure 4b). Structures host multiple small smokers and large overhanging flanges that trap pools of hot fluid (Figure 5c). While small flanges have been observed at some East Pacific Rise vent fields, they attain large sizes and trap significant pools of fluid at the MEF because of the presence of silica, which stabilizes the flanges and prevents them from breaking (Delaney et al., 1992). The large structures that form dominantly by flange growth, diffuse flow through sealed spires and other portions of structures, and incorporation of flanges into edifices are also stabilized by deposition of late-stage silica (Tivey et al., 1999).

The prevalence of amorphous silica at the MEF results from conductive cooling of vent fluids that have high concentrations of ammonia; as tempera- 
Figure 5. (a) Photograph of a black smoker chimney from the southern East Pacific Rise, taken from the submersible Alvin on Dive 3296 (courtesy of Woods Hole Oceanographic Institution (WHOI); M. Lilley and K. Von Damm chief scientists) and a schematic drawing showing a cross section of a black smoker chimney, and likely directions of fluid flow through the conduit, with slower advection and diffusion occurring across the walls. (b) Photograph of a $284^{\circ} \mathrm{C}$ diffusely venting spire from the Vienna Woods vent field in the Manus Basin taken on Jason Dive 207 (courtesy of WHOl; M. Tivey chief scientist), and a schematic drawing of the cross section across an East Pacific Rise diffusely venting spire that is composed of an inner, very porous zone of pyrrhotite $\left(\mathrm{Fe}_{1-x} \mathrm{~S}\right)$, wurtzite $(\mathrm{Zn}, \mathrm{Fe}) \mathrm{S}$, and cubanite ( $\mathrm{CuFe}_{2} \mathrm{~S}_{3}$ ); a less-porous midlayer of wurtzite, pyrite $\left(\mathrm{FeS}_{2}\right)$ and chalcopyrite $\left(\mathrm{CuFeS}_{2}\right)$; and an outer layer of marcasite $\left(\mathrm{FeS}_{2}\right)$ (after Kormas et al., 2006). (c) Photograph of a flange from the Tui Malila vent field, Lau Basin, taken on Jason Dive 134 (courtesy of WHOl; M. Tivey chief scientist), and a schematic drawing showing a cross section of a flange with a trapped pool of high-temperature fluid. Fluids percolate up through the porous flange layers, precipitating minerals as they traverse the steep temperature gradient, or "waterfall" over the lip of the flange. (d) Photograph of diffuse warm fluid exiting the top of a "crust" sample on the upper tier of the TAG mound, taken from Alvin (courtesy of $G$. Thompson, WHOI). Textures of recovered crust samples indicate that much hotter fluid is pooled beneath these crusts within the mound and that the hot fluids percolate upward through cracks. (e) Photograph of low$\mathrm{pH}$ fluids $(\mathrm{pH}<1-2)$ venting from the sides of the flank of the North Su vent field in the eastern Manus Basin, taken on Jason Dive 221 (courtesy of J. Seewald, WHOI). It has been proposed that the very low $\mathrm{pH}$ results from input of magmatic volatiles (e.g., Gamo et al., 1997).

(a) black smoker

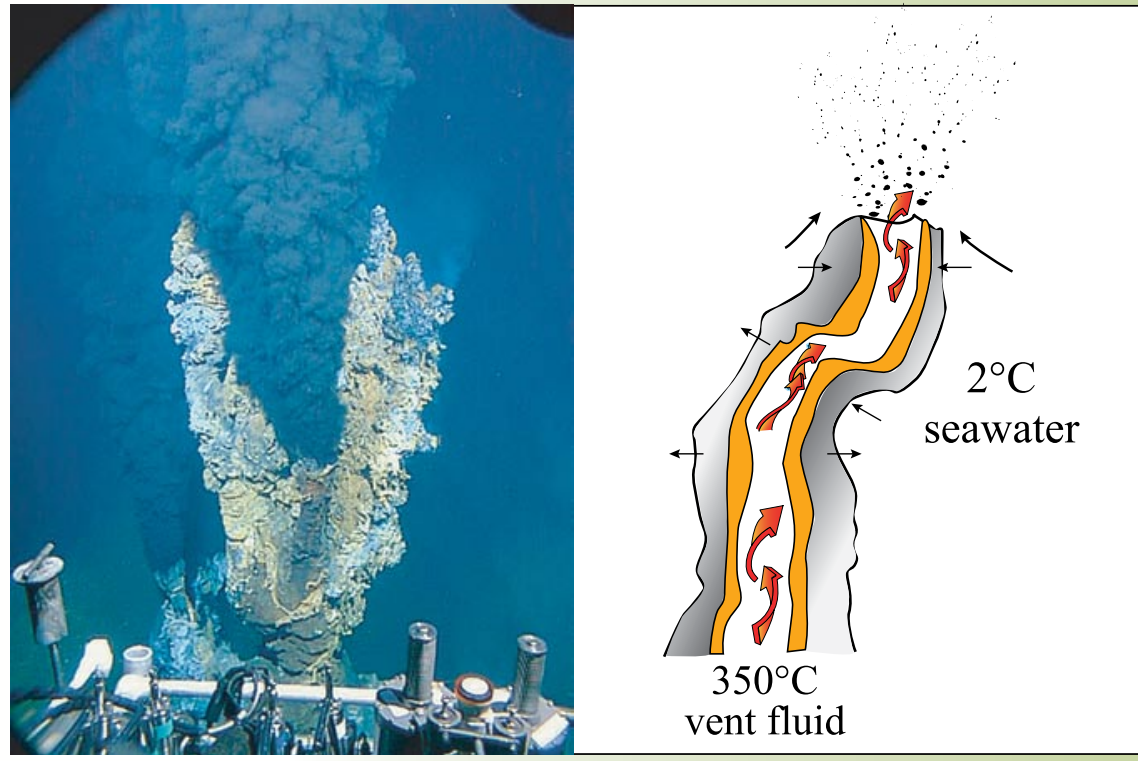

(b) diffuser

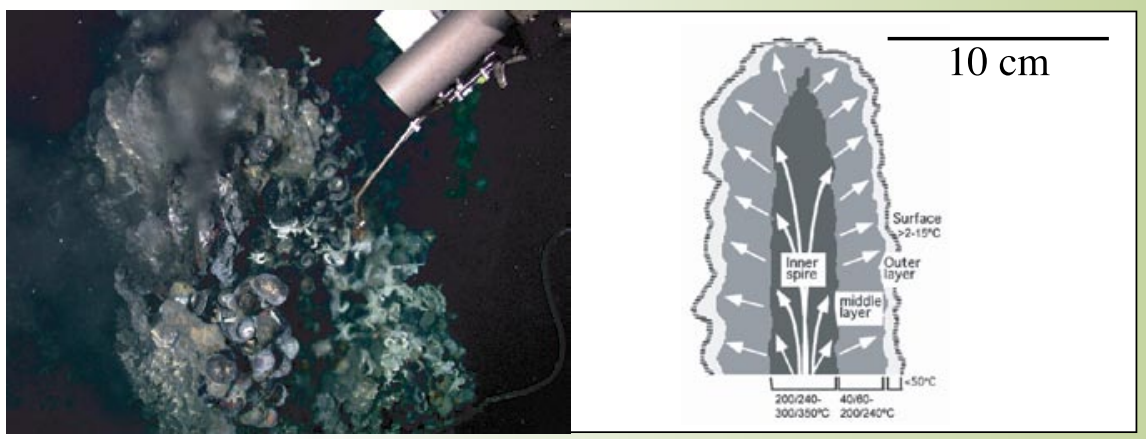

(c) flange

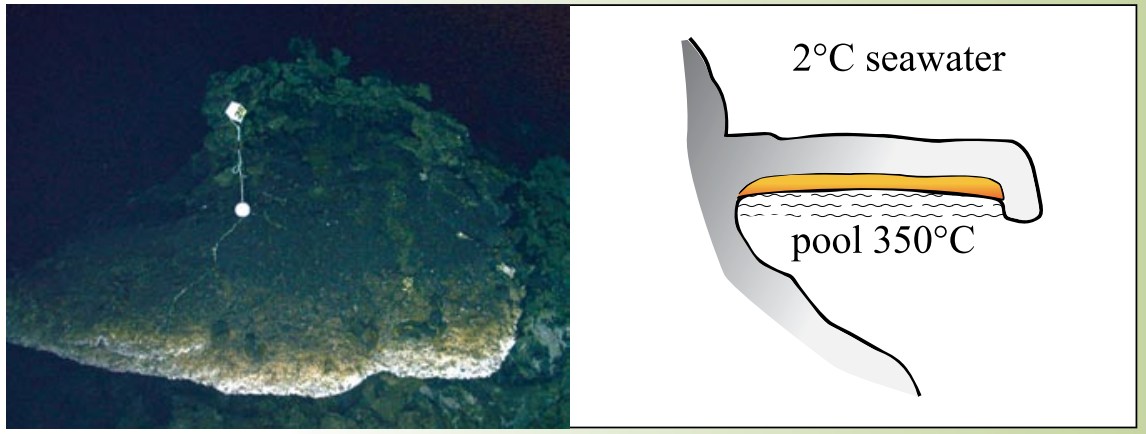

(d) crust

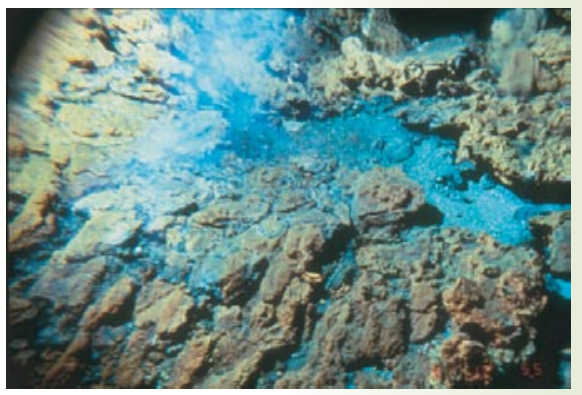

(e) low pH fluids

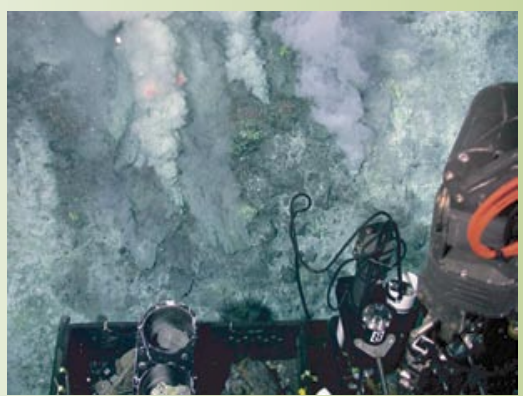


ture decreases, ammonia-ammonium equilibrium buffers $\mathrm{pH}$ and allows more efficient deposition of sulfide minerals and silica from fluids that have a higher $\mathrm{pH}$ than conductively cooled ammonia-poor fluids present at most other mid-ocean ridge vent fields (Tivey et al., 1999). The presence of significant ammonia in the vent fluids is attributed to reaction of fluids with buried organicrich sediments (Lilley et al. 1993). As at East Pacific Rise fields, the variable styles of mixing within the structures_-above flange pools, from chimneys, from fluids percolating through sides of structures or through cracks in the substrateaffect the deposition of minerals and create a range of environments and habitats for organisms.

\section{The TAG Active Hydrothermal Mound-Effects of Seawater Entrainment}

The largest single vent deposit discovered to date along open-ocean spreading centers is the TAG active hydrothermal mound at $26^{\circ} \mathrm{N}$ on the Mid-Atlantic Ridge, where black-smoker fluids are extremely well focused and exit vigorously from a central black-smoker complex to form a large, buoyant black plume (Rona et al., 1986) (Figure 4c). The large size results in part from significant seawater entrainment into the mound, which triggers precipitation of anhydrite, chalcopyrite, and pyrite within the mound, and remobilization of metals (Edmond et al., 1995; Tivey et al., 1995). The large size also reflects the age of the deposit and its formation from repeated episodes of hydrothermal activity over the last 20,000 to 50,000 years (Lalou et al., 1995). Recovery of rock core by the Ocean Drilling Pro- gram exposed a sequence of pyrite, anhydrite, silica, and chloritized basalt breccias and stockwork beneath the mound (Humphris et al., 1995). All fluids exiting the mound, including lower-temperature diffuse fluids, higher-temperature white smoker fluids, and diffuse fluids exiting sulfide-rich crusts on the upper tiers of the mound (Figure 5d), are related through mixing, subsurface deposition, and remobilization (Edmond et al., 1995; James and Elderfield, 1996). This deposit has been noted as an excellent analog of a Cyprus-type massive sulfide deposit (Hannington et al., 1998).

\section{Deposits in Back-Arc Basins,} Submerged Island-Arc Volcanoes, and Rifted Arcs

Vent deposits found at intra-oceanic, back-arc basin spreading centers (e.g., Lau and North Fiji Basins and Mariana Trough), in marginal back-arc basins (e.g., Okinawa Trough), at submerged island-arc volcanoes (e.g., Izu-Bonin, Mariana, and Tonga-Kermadec arcs), and in areas with more complex tectonic histories (e.g., the Manus Basin where arc volcanism and back-arc rifting are occurring in old arc crust) display both similarities and differences when compared with deposits found on mid-ocean ridges (Figure 1). Some deposits are as large as those found along mid-ocean ridges. They can be enriched relative to mid-ocean ridge deposits in $\mathrm{Zn}, \mathrm{Pb}$, $\mathrm{As}, \mathrm{Sb}, \mathrm{Ag}, \mathrm{Au}$, and $\mathrm{Ba}$ (see reviews by Ishibashi and Urabe, 1995; Hannington et al., 2005). For example, deposits hosted in basalt in the northern Lau Basin are not enriched in trace metals relative to mid-ocean ridge deposits (Bortnikov et al., 1993), while those hosted in an- desite at the $400 \mathrm{~m} \times 100 \mathrm{~m}$ Vai Lili field on the Valu Fa Ridge in the southern Lau Basin are rich in barite $\left(\mathrm{BaSO}_{4}\right)$, sphalerite $((\mathrm{Zn}, \mathrm{Fe}) \mathrm{S}))$, tennantite $\left(\mathrm{Cu}_{12} \mathrm{As}_{4} \mathrm{~S}_{13}\right)$, and galena $(\mathrm{PbS})$ relative to mid-ocean ridge deposits (Fouquet et al., 1993a). At the Brothers volcano in the Kermadec island arc, located at a water depth of $1600 \mathrm{~m}$, active black smokers and massive sulfide deposits are present on the caldera wall, as are sulfur-rich fumaroles and very-low-pH vent fluids (de Ronde et al., 2005). At the PACMANUS vent area on Pual Ridge in the eastern Manus Basin, sulfide deposits are enriched in $\mathrm{Au}, \mathrm{Ag}, \mathrm{Pb}, \mathrm{As}, \mathrm{Sb}$, and Ba relative to mid-ocean ridge deposits (Scott and Binns, 1995; Moss and Scott, 2001; Binns et al., 2002). At the DESMOS caldera, farther east in the Manus Basin, advanced argillic alteration of the lavas is observed (i.e., alteration of igneous rocks to alunite $\left(\mathrm{KAl}_{3}\left(\mathrm{SO}_{4}\right)_{2}(\mathrm{OH})_{6}\right)$, aluminum-rich clay, and quartz \pm pyrite), proposed to result from alteration by acidsulfate fluids; vent fluids with extremely low $\mathrm{pH}$ (as low as 0.87 ) are also present (Gamo et al., 1997; Seewald et al., 2006).

The differences and similarities observed in the composition of deposits present in back-arc basins, rifted arcs, and submerged island-arc volcanoes can be attributed to a number of factors, including the composition of the substrate (basalt, andesite, rhyolite, dacite), the contribution of magmatic volatiles to the hydrothermal system, and the depth and structure of the substrate. However, because many of these factors co-vary with one another, it is difficult to determine which is most responsible for observed differences in deposits. For example, deposits hosted in basalt in 
back-arc basins (e.g., in the northern Lau

Basin and in the Manus Basin) are most similar in composition and structure to mid-ocean ridge deposits; these deposits, however, are also present in water depths most similar to those observed at mid-ocean ridges (e.g., Bortnikov et al., 1993; Hannington et al., 2005). In contrast, deposits hosted in andesite, rhyolite, and dacite (e.g., those on the Valu Fa Ridge in the Lau Basin, on Brothers volcano in the Kermadec island arc, and on the Pual Ridge in the eastern Manus Basin) exhibit metal enrichments relative to mid-ocean ridge deposits. The more felsic (or siliceous) substrate compositions (andesite, rhyolite, dacite) reflect effects of the addition of $\mathrm{H}_{2} \mathrm{O}$ and other volatiles from subducted sediments and hydrated oceanic crust, and partial melting in the mantle wedge (see review by Hannington et al., 2005). These deposits, however, are also located in shallower water depths, and low-pH fluids at these sites suggest the addition of magmatic volatiles (e.g., $\mathrm{SO}_{2}$ ) (see reviews by Ishibashi and Urabe, 1995 and Hannington et al., 2005). So, while the observed metal enrichments in deposits (e.g., of $\mathrm{Zn}, \mathrm{Pb}$, $\mathrm{As}, \mathrm{Sb}, \mathrm{Ag}, \mathrm{Au}$, and $\mathrm{Ba}$ ) are attributed to vent fluids being enriched in these elements from reaction of seawater with rocks that are richer in silica and water (e.g., Fouquet et al., 1993a; Scott and Binns, 1995), the enrichments are also thought to result from input of magmatic volatiles into these systems, such as $\mathrm{SO}_{2}$, which results in a more acidic hydrothermal fluid that can mobilize more metals (Figure 5e) (e.g., Douville et al., 1999; Gamo et al., 1997).

There is evidence for the presence of magmatic $\mathrm{SO}_{2}$ at a number of back-arc and island-arc vent sites. Anomalously low-sulfur isotope values of sulfides $\left(\delta^{34} \mathrm{~S}\right.$ as low as $-7.3 \%$ o to $-13.9 \%$ ) at Brothers volcano in the Kermadec arc, the DESMOS caldera in the Manus back-arc basin, the Hine Hina vent field in the Lau Basin, and Conical Seamount near Papua New Guinea are consistent with input of magmatic $\mathrm{SO}_{2}$ to these systems (see review by Hannington et al., 2005). It has also been proposed that magmatic fluids at some sites may carry metals in addition to $\mathrm{SO}_{2}$, so that some of the metal enrichment could be from direct input of magmatic fluids to the hydrothermal systems. Evidence for this includes the presence of high concentrations of $\mathrm{Cu}, \mathrm{Zn}$, and Fe sulfides and chlorides in $\mathrm{CO}_{2}$-rich gas bubbles in both melt inclusions and matrix glass of volcanic rocks recovered from the eastern Manus back-arc basin (Yang and Scott, 1996). In addition, high concentrations of $\mathrm{Au}$ and As in back-arc and arc-related massive sulfide deposits have been proposed to reflect magmatic input, given the extreme enrichments in deposits relative to host rocks, and that such enrichments are unlikely to occur solely from leaching from host rocks (Ishibashi and Urabe, 1995; Hannington et al., 2005).

Two additional factors, the shallow water depth of many arc and back-arc related systems, and differences in the structure of felsic vs. basaltic oceanic crust, may also modify fluid compositions and affect metal enrichments. At submarine volcanic arcs, vents are located on conical volcanoes, sometimes within a summit caldera, and often in water depths that are $<1000 \mathrm{~m}$. At these shallow depths, boiling of fluids may occur as they ascend from depth, and this boiling can enhance metal enrichments (Hannington et al., 2005).

Volcanism in shallower water can also result in pyroclastic rock (e.g., Fiske et al., 2001) that is very porous, with much greater permeability than lavas erupted in deeper water. If permeability is enhanced, then seawater entrainment may occur, with subsurface deposition of sulfide minerals and anhydrite, generation of a more acidic fluid, and subsequent metal remobilization that could lead to further metal enrichment. It has been proposed that the more siliceous magmas in back-arc and arc environments result in substrates with greater permeability, also allowing greater amounts of seawater entrainment (Butterfield et al., 2003). Further detailed study of the fluids and deposits in these settings should allow better constraints to be placed on the roles that substrate composition, substrate structure, and magmatic volatile contribution play in determining vent fluid and vent deposit composition.

\section{Calcite-Rich "Lost City" \\ Type Deposits}

For each setting described above, differences in the size, morphology, and composition of vent structures have been attributed to some combination of differences in vent fluid composition (e.g., $\mathrm{pH}$, presence or absence of ammonia at the MEF), style of mixing between vent fluid and seawater (e.g., rapid venting of vent fluid into the ocean at the East Pacific Rise vs. mixing of vent fluid with entrained seawater beneath the seafloor as at TAG), and longevity of venting (related to spreading rate, eruption frequency). At the Lost City vent field, the fluid composition is extremely 
different from mid-ocean ridge or backarc basin vent fluids, with an alkaline $\mathrm{pH}(\sim 10-11)$ and low metal and sulfide content (Kelley et al. 2005; Proskurowski et al., 2006) (Table 1). The fluids exiting the structures are also significantly cooler than at many seafloor vent sites, with maximum observed temperatures of $91^{\circ} \mathrm{C}$ (Kelley et al., 2005). The deposits present are tall spires with flanges. Active portions consist of porous and friable networks of aragonite $\left(\mathrm{CaCO}_{3}\right)$ enclosed in brucite $\left(\mathrm{Mg}(\mathrm{OH})_{2}\right)$; aragonite becomes saturated and precipitates as high-pH, Ca-rich fluids mixes with $\mathrm{Ca}$ - and bicarbonate $\left(\mathrm{HCO}_{3}^{-}\right)$- rich seawater, while brucite forms as warm, high-pH (thus hydroxide $\left(\mathrm{OH}^{-}\right)$-rich) vent fluid mixes with $\mathrm{Mg}$-rich seawater (Kelley et al., 2005, Kelley, 2005). Older, inactive portions of the structures are calcite-rich, lithified, and brucite-poor, a result of aragonite converting to calcite over time, and brucite dissolving as it is exposed to cold seawater that percolates into older parts of the structure (Kelley et al., 2001, 2005).

The Lost City structures differ significantly from other seafloor vent deposits in composition. They lack metal-sulfide minerals because of a lack of metals and sulfide in the vent, and they lack anhydrite $\left(\mathrm{CaSO}_{4}\right)$ because mixing temperatures are low $\left(<91^{\circ} \mathrm{C}\right)$, preventing anhydrite-saturation, and $\mathrm{pH}$ is high, resulting in saturation of aragonite $\left(\mathrm{CaCO}_{3}\right)$ during mixing (Kelley et al., 2005). The large size of the structures, however, is attributed to factors similar to those responsible for the large size of the TAG active hydrothermal mound. Efficient mineral deposition occurs at both sites from seawater entrainment into the subsurface at TAG, and from mixing of warm, very-high-pH, reduced $\left(\mathrm{H}_{2}\right.$-rich) vent fluid with seawater at Lost City. More importantly, there is evidence that both systems have been active on and off for tens of thousands of years (30,000 years based on ${ }^{14} \mathrm{C}$ dating of the Lost City deposits (Fruh-Green et al., 2003) and 20,000 to 50,000 years at TAG (Lalou et al., 1995), with the longevity a result of slow rates of spreading and low eruption frequency.

\section{SUMMARY}

Despite the wide range in spreading rates, depths, substrate compositions, and geometries or even types of heat sources (e.g., serpentinization reactions vs. presence of magma) along mid-ocean ridge and back-arc basin spreading centers, and at submerged arc volcanoes and rifted arcs, there are strong similarities among all seafloor vent fields in terms of the processes of heat and mass transfer that result in venting of hydrothermal fluids to the oceans, formation of mineral deposits, and creation of chemical and thermal environments conducive to biological activity in the deep sea. By comparing the fluids and deposits formed in distinct geologic and tectonic settings, it is possible to examine the role that specific factors play in determining fluid composition (e.g., substrate composition, input of magmatic volatiles, permeability structure of the substrate, geometry and nature of heat source, temperatures and pressures at which reactions occur) and mineral deposit size, shape, and composition (e.g., vent fluid composition, styles of mixing between fluids, longevity of venting). Future progress in understanding the impact that hydrothermal systems have on Earth processes will be made through taking advantage of the range in tectonic and geologic settings of venting. Many of the world's spreading centers have yet to be explored (Figure 1), particularly in the polar regions on ultraslow-spreading ridges. As always in oceanography, progress will continue to be made through a combination of hypothesis-driven exploration and serendipity.

\section{ACKNOWLEDGEMENTS}

Support for M.K.T. was provided by National Science Foundation grants OCE-0241796 and OCE0327448. Illustrations were done by Margaret Sulanowska with help from Lauren Ledwell. Reviews by Sven Petersen and David Vanko are gratefully acknowledged. एव

\section{REFERENCES}

Allen, D.E., and W.E. Seyfried Jr. 2003. Compositional controls on vent fluids from ultramafic-hosted hydrothermal systems at mid-ocean ridges: An experimental study at $400^{\circ} \mathrm{C}, 500$ bars. Geochimica et Cosmochimica Acta 67:1,531-1,542.

Allen, D.E., and W.E. Seyfried Jr. 2004. Serpentinization and heat generation: Constraints from Lost City and Rainbow hydrothermal systems. Geochimica et Cosmochimica Acta 68:1,347-1,354.

Alt, J. 1995. Subseafloor processes in mid-ocean ridge hydrothermal systems. Pp. 85-114 in Seafloor Hydrothermal Systems: Physical, Chemical, Biological, and Geological Interactions. S.E. Humphris, R.A. Zierenberg, L.S. Mullineaux, and R.E. Thomson, eds, AGU Monograph Series, No. 91, American Geophysical Union, Washington, DC.

Baker, E., C.R. German, and H. Elderfield. 1995. Hydrothermal plumes over spreading-center axes: Global distributions and geological inferences. Pp. 47-71 in Seafloor Hydrothermal Systems: Physical, Chemical, Biological, and Geological Interactions. S.E. Humphris, R.A. Zierenberg, L.S. Mullineaux, and R.E. Thomson, eds, AGU Monograph Series, No. 91, American Geophysical Union, Washington, DC.

Baker, E.T., H.N. Edmonds, P.J. Michael, W. Bach, H.J.B. Dick, J.E. Snow, S.L. Walker, N.R. Banerjee, 
and C.H. Langmuir. 2004. Hydrothermal venting in magma deserts: The ultraslow-spreading Gakkel and Southwest Indian Ridges. Geochemistry Geophysics Geosystems 5:Q08002, doi:10.1029/ 2004GC000712.

Binns, R.A., F.J.S. Barriga, and D.J. Miller. 2002. Anatomy of an active felsic-hosted hydrothermal system, eastern Manus Basin-Summary. Pp. 184 in Proceedings of the Ocean Drilling Program, Initial Reports [CD-ROM] 193, Ocean Drilling Program, College Station, TX.

Bischoff, J.L., and W.E. Seyfried Jr. 1978. Hydrothermal chemistry of seawater from $25^{\circ}$ to $350^{\circ} \mathrm{C}$. American Journal of Science 278:838-860.

Bischoff, J.L., and R.J. Rosenbauer. 1985. An empirical equation of state for hydrothermal seawater (3.2 percent $\mathrm{NaCl}$ ). American Journal of Science 285:725-763.

Bortnikov, N.S., D.T. Fedorov, and K.G. Murav'ev. 1993. Mineral composition and conditions of the formation of sulfide edifices in the Lau Basin (southwestern sector of the Pacific Ocean). Geology of Ore Deposits 35:476-488.

Butterfield, D.A., Y. Fouquet, M. Halbach, P.E. Halbach, S.E. Humphris, M.D. Lilley, V. Luders, S. Petersen, W.E. Seyfried, Jr., M. Shimizu, and M.K. Tivey. 2003. Group report: How can we describe fluid-mineral processes and the related energy and material fluxes? Pp. 183-209 in Energy and Mass Transfer in Marine Hydrothermal Systems. P.E. Halbach, V. Tunnicliffe, and J.R. Hein, eds, Dahlem Workshop Report 89, Dahlem University Press, Berlin.

Butterfield, D.A., K.K. Roe, M.D. Lilley, J.A. Huber, J.A. Baross, R.W. Embley, and G.J. Massoth. 2004. Mixing, reaction and microbial activity in the sub-seafloor revealed by temporal and spatial variation in diffuse flow vents at Axial Volcano. Pp. 269-289 in Subseafloor Biosphere at MidOcean Ridges. W. Wilcock, C. Cary, E. DeLong, D. Kelley, and J. Baross, eds, Geophysical Monograph Series, No. 144, American Geophysical Union, Washington, DC.

Corliss, J.B., J. Dymond, L.I. Gordon, J.M. Edmond R.P. von Herzen, R.D. Ballard, K. Green, D. Williams, A. Bainbridge, K. Crane, and T.H. van Andel. 1979. Submarine thermal springs on the Galapagos Rift. Science 203:1,073-1,083.

Delaney, J.R., V. Robigou, R.E. McDuff, and M.K. Tivey. 1992. Geology of a vigorous hydrothermal system on the Endeavour segment, Juan de Fuca Ridge. Journal of Geophysical Research 97:19,66319,682 .

Delaney, J.R., D.W. Mogk, and M.J. Mottl. 1987. Quartz-cemented breccias from the Mid-Atlantic Ridge: Samples of a high-salinity hydrothermal upflow zone. Journal of Geophysical Research 92:9,175-9,192.

de Ronde, C.E.J., M.D. Hannington, P. Stoffers, I.C. Wright, R.G. Ditchburn, A.G. Reyes, E.T. Baker, G.J. Massoth, J.E. Lupton, S.L. Walker, R.R. Greene, C.W.R. Soong, J. Ishibashi, G.T. Lebon,
C.J. Bray, and J.A. Resing. 2005. Evolution of a submarine magmatic-hydrothermal system: Brothers volcano, southern Kermadec arc, New Zealand. Economic Geology 100:1,097-1,134.

Ding, K., and W.E. Seyfried Jr. 1994. Effect of conductive cooling on chemistry of mid-ocean ridge hydrothermal fluids: Experimental and theoretical constraints. Mineralogical Magazine 58A:231-232.

Douville, E., P. Bienvenu, J.-L. Charlou, J.-P. Donval, Y. Fouquet, P. Appriou, and T. Gamo. 1999. Yttrium and rare earth elements in fluids from various deep-sea hydrothermal systems. Geochimica et Cosmochimica Acta 63:627-643.

Douville E., J.L. Charlou, E.H. Oelkers, P. Bienvenu, C.F.J. Colon, J.P. Donval, Y. Fouquet, D. Prieur, and P. Appriou. 2002. The rainbow vent fluids ( $\left.36^{\circ} 14^{\prime} \mathrm{N}, \mathrm{MAR}\right)$ : The influence of ultramafic rocks and phase separation on trace metal content in Mid-Atlantic Ridge hydrothermal fluids. Chemical Geology 184:37-48.

Edmond, J.M., A.C. Campbell, M.R. Palmer, G.P. Kinkhammer, C.R. German, H.N. Edmonds, H. Elderfield, G. Thompson, and P. Rona. 1995. Time series of vent fluids from the TAG and MARK sites $(1986,1990)$ Mid-Atlantic Ridge: A new solution chemistry model and a mechanism for $\mathrm{Cu} / \mathrm{Zn}$ zonation in massive sulphide orebodies. Pp. 77-86 in Hydrothermal Vents and Processes. L.M. Parson, C.L. Walker, and D.R. Dixon, eds, Geological Society of London Special Publications.

Ferrini, V.L., D.J. Fornari, T.M. Shank, J.C. Kinsey, M.A. Tivey, S.A. Soule, S.M. Carbotte, L.L. Whitcomb, D. Yoerger, and J. Howland. In press. Submeter bathymetric mapping of volcanic and hydrothermal features on the East Pacific Rise Crest at $9^{\circ} 50^{\prime} \mathrm{N}$. Geochemistry Geophysics Geosystems.

Fiske, R.S., J. Nada, K. Iizasa, M. Yuasa, and A. Klaus. 2001. Submarine silicic caldera at the front of the Izu-Bonin arc, Japan: Voluminous seafloor eruptions of rhyolite pumice. Geological Society of America Bulletin 113:813-824.

Fouquet, Y., U. Von Stackelberg, J.-L. Charlou, J. Erzinger, P. Herzig, R. Mühe, and M.Wiedicke. 1993a. Metallogenesis in back-arc environments: The Lau Basin example. Economic Geology 88:2,154-2,181.

Fouquet, Y., A. Wafik, P. Cambon, C. Mevel, G. Meyer, and P. Gente. 1993b. Tectonic setting, mineralogical and geochemical zonation in the Snake Pit sulfide deposit (Mid-Atlantic Ridge at $23^{\circ} \mathrm{N}$ ). Economic Geology 88:2,018-2,036.

Fruh-Green, G.L., D.S. Kelley, S.M. Bernasconi, J.A. Karson, K.A. Ludwig, D.A. Butterfield, C. Bischi, and G. Proskurowski. 2003. 30,000 years of hydrothermal activity at the Lost City vent field. Science 301:495-498.

Gamo, T., K. Okamura, J.-L. Charlou, T. Urabe, J.-M. Auzende, J. Ishibashi, K. Shitashima, H. Chiba, and Manusflux Scientific Party. 1997. Acidic and sulphate-rich hydrothermal fluids from the Ma- nus back-arc basin, Papua New Guinea. Geology 25:139-142.

German, C.R., and K.L. Von Damm. 2004. Hydrothermal processes. Pp. 181-222 in Treatise On Geochemistry, Volume 6: The Oceans and Marine Geochemistry. H.D. Holland and K.K. Turekian, eds, Elsevier, London.

Goldfarb, M.S., D.R. Converse, H.D. Holland, and J.M. Edmond. 1983. The genesis of hot spring deposits on the East Pacific Rise, $21^{\circ}$ N. Economic Geology Monograph 5:184-197.

Hajash, A., and G.W. Chandler. 1981. An experimental investigation of high- temperature interactions between seawater and rhyolite, andesite, basalt, and peridotite. Contributions to Mineralogy and Petrology 78:240-254.

Hannington, M.D., I.R. Jonasson, P.M. Herzig, and S. Petersen. 1995. Physical and chemical processes of seafloor mineralization at mid-ocean ridges, Pp. 115-157 in Seafloor Hydrothermal Systems: Physical, Chemical, Biological, and Geological Interactions. S.E. Humphris, R.A. Zierenberg, L.S. Mullineaux, and R.E. Thomson, eds, AGU Monograph Series, No. 91, American Geophysical Union, Washington, DC.

Hannington, M.D., A.D. Galley, P.M. Herzig, and S. Petersen. 1998. Comparison of the TAG mound and stockwork complex with Cyprus-type massive sulfide deposits. Pp. 389-415 in Proceedings of the Ocean Drilling Program, Scientific Results, v. 158. P.M. Herzig, S.E. Humphris D.J. Miller, and R.A. Zierenberg, eds, Ocean Drilling Program, College Station, TX.

Hannington, M.D., C.E.J. de Ronde, and S. Petersen. 2005. Sea-floor tectonics and submarine hydrothermal systems. Pp. 111-141 in 100th Anniversary Volume of Economic Geology. J. Hedenquist et al., eds, Society of Economic Geologists, Littleton, Colorado.

Haymon, R.M., and M. Kastner. 1981. Hot spring deposits on the East Pacific Rise at $21^{\circ} \mathrm{N}$ : Preliminary description of mineralogy and genesis. Earth and Planetary Science Letters 53:363-381.

Haymon, R. 1983. Growth history of hydrothermal black smoker chimneys. Nature 301:695-698.

Helgeson, H.C., D.H. Kirkham, and G.C. Flowers. 1981. Theoretical prediction of the thermodynamic behavior of aqueous electrolytes at high pressures and temperatures. IV. Calculation of activity coefficients, osmotic coefficients, and apparent molal and standard and relative partial molal properties to $600^{\circ} \mathrm{C}$ and $5 \mathrm{kbar}$. American Journal of Science 281:1,249-1,517.

Humphris, S.E., P.M. Herzig, D.J Miller, J.C. Alt, K. Becker, D. Brown, G. Burgmann, H. Chiba, Y. Fouquet, J.B. Gemmell, G. Guerin, M.D. Hannington, N.G. Holm, J.J. Honnorez, G.J. Iturrino, R. Knott, R. Ludwig, K. Nakamura, S. Petersen, A.-L. Reysenbach, P.A. Rona, S. Smith, A.A. Sturz, M.K. Tivey, and X. Zhao. 1995. The internal structure of an active sea-floor massive sulphide deposit. Nature: 377:713-716. 
Humphris, S.E., and M.K. Tivey. 2000. A synthesis of geological and geochemical investigations of the TAG Hydrothermal Field: Insights into fluid flow and mixing processes in a hydrothermal system. Pp. 213-235 in Ophiolites and Oceanic Crust: New Insights from Field Studies and the Ocean Drilling Program. Y. Dilek, E. Moores, D. Elthon, A. Nicholas, eds, Geological Society of America Special Paper 349, Boulder, CO.

Ishibashi J.-I., and T. Urabe T. 1995. Hydrothermal activity related to arc-backarc magmatism in the western Pacific. Pp. 451-495 in Backarc Basins: Tectonics and Magmatism. B. Taylor, ed., Plenum, New York, NY.

James, R.H., and H. Elderfield. 1996. Chemistry of ore-forming fluids and mineral formation rates in an active hydrothermal sulfide deposit on the Mid-Atlantic Ridge. Geology 24:1,147-1,150.

Kelley, D.S., K.M. Gillis, and G. Thompson. 1993. Fluid evolution in submarine magma-hydrothermal systems at the Mid-Atlantic Ridge. Journal of Geophysical Research 98:19,579-19,596.

Kelley D.S., J.A. Karson, D.K. Blackman, G.L. FruhGreen, D.A. Butterfield, M.D. Lilley, E.J. Olson, M.O. Schrenk, K.K. Roe, G.T. Lebon, P. Rivizzigno, and the AT3-60 shipboard party. 2001. An off-axis hydrothermal vent field near the Mid-Atlantic Ridge at $30^{\circ} \mathrm{N}$. Nature 412:145-149.

Kelley, D.S., J.A. Karson, G.L. Fruh-Green, D.R. Yoerger, T.M. Shank, D.A. Butterfield, J.M. Hayes, M.O. Schrenk, E.J. Olson, G. Proskurowski, M. Jakuba, A. Bradley, B. Larson, K. Ludwig, D. Glackson, K. Buckman, A.S. Bradley, W.J. Brazelton, K. Roe, M.J. Elend, A. Delacour, S.M. Bernasconi, M.D. Lilley, J.A. Baross, R.E. Summons, and S.P. Sylva. 2005. A serpentinite-hosted ecosystem: The Lost City Hydrothermal Field. Science 307:1,428-1,434.

Kelley, D.S. 2005. From the mantle to microbes: The Lost City Hydrothermal Field. Oceanography 18(3):32-45.

Kormas, K., M.K. Tivey, K.L. Von Damm, and A. Teske. 2006. Bacterial and archaeal phylotypes associated with distinct mineralogical layers of a white smoker spire from a deep-sea hydrothermal vent site ( $9^{\circ} \mathrm{N}$, East Pacific Rise). Environmental Microbiology 8(5):909-920.

Koschinsky, A., A. Billings, C. Devey, N. Dubilier, A. Duester, D. Edge, D. Garbe-Schonberg, C. German, O. Giere, R. Keir, K. Lackschewitz, H.A. Mai, H. Marbler, J. Mawick, B. Melchert, C. Mertens, M. Peters, S. Sander, O. Schmale, W. Schmidt, R. Seifert, C. Seiter, U. Stober, I. Suck, M. Walter, S. Weber, D. Yoerger, M. Zarrouk, and F. Zielinski. 2006. Discovery of new hydrothermal vents on the southern Mid-Atlantic Ridge $\left(4^{\circ} \mathrm{S}-10^{\circ} \mathrm{S}\right)$ during cruise M68/1. InterRidge News 15:9-15.

Koski, R.A., I.R. Jonasson, D.C. Kadko, V.K. Smith, and F.L. Wong. 1994. Compositions, growth mechanisms, and temporal relations of hydrothermal sulfide-sulfate-silica chimneys at the northern Cleft segment, Juan de Fuca Ridge.
Journal of Geophysical Research 99:4,813-4,832.

Lalou, C., J.L. Reyss, E. Brichet, P.A. Rona, and G. Thompson. 1995. Hydrothermal activity on a $10^{5}$-year scale at a slow-spreading ridge, TAG hydrothermal field, Mid-Atlantic Ridge $26^{\circ} \mathrm{N}$. Journal of Geophysical Research 100:17,855-17,862.

Lilley, M.D., D.A. Butterfield, E.J. Olson, J.E. Lupton, S.A. Macko, and R.E. McDuff. 1993. Anomalous $\mathrm{CH}_{4}$ and $\mathrm{NH}_{4}^{+}$concentrations at an unsedimented mid-ocean ridge hydrothermal system. Nature 364:45-47.

Moss, R., and S.D. Scott. 2001. Geochemistry and mineralogy of gold-rich hydrothermal precipitates from the eastern Manus Basin, Papua New Guinea. Canadian Mineralogist 39:957-978.

Mottl, M.J. 1983. Metabasalts, axial hot springs, and the structure of hydrothermal systems at midocean ridges. Geological Society of America Bulletin 94:161-180.

Proskurowski, G., M.D. Lilley, D.S. Kelley, and E.J. Olson. 2006. Low temperature volatile production at the Lost City Hydrothermal Field, evidence from a hydrogen stable isotope geothermometer. Chemical Geology 229:331-343.

Rona, P.A., G. Klinkhammer, T.A. Nelsen, J.H. Trefry, and H. Elderfield. 1986. Black smokers, massive sulfides and vent biota at the Mid-Atlantic Ridge. Nature 321:33-37.

Sarrazin J., S.K. Juniper, V. Robigou, and J.R. Delaney. 1997. Biological and geological dynamics over four years on a high-temperature sulfide structure at the Juan de Fuca Ridge hydrothermal observatory. Marine Ecology Progress Series 153:5-24.

Scott, S.D., and R.A. Binns. 1995. Hydrothermal processes and contrasting styles of mineralization in the western Woodlark and eastern Manus Basins of the western Pacific. Pp. 473-205 in Hydrothermal Vents and Processes. L.M. Parson, C.L. Walker, and D.R. Dixon, eds, Geological Society of London Special Publications.

Seewald, J., E. Reeves, P. Saccocia, O. Rouxel, E. Walsh, R. Price, M.A. Tivey, W. Bach, M.K. Tivey, and the Scientific Party of MGLN06. 2006. Water-Rock Reaction, Substrate Composition, Magmatic Degassing, and Mixing as Major Factors Controlling Vent Fluid Compositions in Manus Basin Hydrothermal Systems. Eos, Transactions, American Geophysical Union 87(52), Fall Meeting Supplement, Abstract B34A-02.

Skinner, B.J. 1983. Submarine volcanic exhalations that form mineral deposits: An old idea now proven correct. Pp. 557-569 in Hydrothermal Processes at Seafloor Spreading Centres. P.A. Rona, K. Boström, L. Laubier, and K. L. Smith, eds, NATO Conference Series IV:12, Plenum Publishing Corp., New York, N.Y.

Talwani, M., C.C. Windisch, and M.G. Langseth Jr. 1971. Reykjanes ridge crest: A detailed geophysical study. Journal of Geophysical Research 76:473-517.

Tivey, M.K., S.E. Humphris, G. Thompson, M.D.
Hannington, and P. Rona. 1995. Deducing patterns of fluid flow and mixing within the active TAG hydrothermal mound using mineralogical and geochemical data. Journal of Geophysical Research 100:12,527-12,555.

Tivey, M.K., D.S. Stakes, T.L. Cook, M.D. Hannington, and S. Petersen. 1999. A model for growth of steep-sided vent structures on the Endeavour Segment of the Juan de Fuca Ridge: Results of a petrologic and geochemical study. Journal of Geophysical Research 104:22,859-22,883.

Trefry, J.H., D.A. Butterfield, S. Metz, G.J. Massoth, R.P. Trocine, and R.A. Feely. 1994. Trace metals in hydrothermal solutions from Cleft Segment on the southern Juan de Fuca Ridge. Journal of Geophysical Research 99:4,925-4,935.

Vanko, D.A. 1988. Temperature, pressure and composition of hydrothermal fluids, with their bearing on the magnitude of tectonic uplift at mid-ocean ridges, inferred from fluid inclusions in oceanic layer 3 rocks. Journal of Geophysical Research 93:4,595-4,611.

Von Damm K.L., J.M. Edmond, B. Grant, C.I. Measures, B. Walden, and R.F. Weiss. 1985. Chemistry of submarine hydrothermal solutions at $21^{\circ} \mathrm{N}$, East Pacific Rise. Geochimica et Cosmochimica Acta 49:2,197-2,220.

Von Damm, K.L. 1995. Controls on the chemistry and temporal variability of seafloor hydrothermal fluids. Pp. 222-247 in Seafloor Hydrothermal Systems: Physical, Chemical, Biological, and Geological Interactions. S.E. Humphris, R.A. Zierenberg, L.S. Mullineaux, and R.E. Thomson, eds, AGU Monograph Series, No. 91, American Geophysical Union, Washington, DC.

Von Damm, K.L., and M.D. Lilley. 2004. Diffuse flow hydrothermal fluids from $9^{\circ} 50$ 'N East $\mathrm{Pa}$ cific Rise: Origin, evolution and biogeochemical controls. Pp. 245-268 in Subseafloor Biosphere at Mid-Ocean Ridges. W. Wilcock, C. Cary, E. DeLong, D. Kelley, and J. Baross, eds, Geophysical Monograph Series, No. 144, American Geophysical Union, Washington, DC.

Welhan J., and H. Craig. 1983. Methane, hydrogen, and helium in hydrothermal fluids at $21^{\circ} \mathrm{N}$ on the East Pacific Rise. Pp. 391-409 in Hydrothermal Processes at Seafloor Spreading Centres. P.A. Rona, K. Boström, L. Laubier, and K. L. Smith, eds, NATO Conference Series IV:12, Plenum Publishing Corp., New York, NY.

Wetzel, L.R., and E.L. Shock. 2000. Distinguishing ultra-mafic from basalt-hosted submarine hydrothermal systems by comparing calculated vent fluid compositions. Journal of Geophysical Research 105:8,319-8,340.

Yang, K., and S.D. Scott. 1996. Possible contribution of a metal-rich magmatic fluid to a sea-floor hydrothermal system. Nature 383:420-423. 